J. Med. Microbiol. - Vol. 25 (1988), 253-259

(C) 1988 The Pathological Society of Great Britain and Ireland

\title{
Nitrate- and nitrite-reducing bacteria in the achlorhydric stomach
}

\author{
S. J. FORSYTHE*, J. M. DOLBY†, A. D. B. WEBSTER $\ddagger$ and J. A. COLE
}

Department of Biochemistry, University of Birmingham, PO Box 363, Birmingham B15 2TT and Divisions of †Communicable Diseases and $\ddagger /$ mmunological Medicine, Clinical Research Centre, Watford Road, Harrow HA1 3UJ

Summary. The microbial composition of samples of gastric juice from eight achlorhydric patients was determined by aerobic and rigorously anaerobic culture techniques. Bacteria from 16 genera were commonly isolated, but representatives of only three genera, (streptococci, neisseriae and haemophili) were isolated from every patient. Nitrate and nitrite were both reduced by veillonellae, haemophili, staphylococci, corynebacteria, lactobacilli, flavobacteria and fusobacteria, but the potential rate of nitrate reduction by suspensions of veillonellae, Haemophilus parainfluenzae and members of the Enterobacteriaceae were up to ten times more rapid than the rate of nitrite reduction. Conversely, although all Neisseria spp. reduced nitrite only some strains reduced nitrate. Streptococci did not reduce nitrate. Streptococcus sanguis reduced nitrite when grown with haematin; other streptococci did not reduce nitrite. Bacterial nitrate and nitrite reduction were active over the $p \mathrm{H}$ range 6-8, similar to the $p \mathrm{H}$ range of the achlorhydric stomach.

From a knowledge of the composition of the bacterial flora and their potential rates of nitrate and nitrite reduction under prevailing conditions, predictions were made about the tendency of nitrite to accumulate during nitrate reduction. Studies of the transient accumulation of nitrite by mixed cultures of $H$. parainfluenzae and $N$. subflava were consistent with these predictions. Haemophili and veillonellae could be responsible for the accumulation of nitrite in the gastric juice of some patients, whereas streptococci and neisseriae would tend to remove nitrite from the stomach as rapidly as it formed.

\section{Introduction}

The metabolic activity of the bacterial flora that becomes established in the stomachs of achlorhydric patients has been studied intensively because it is implicated in the formation of carcinogenic compounds. Gastric cancer is fifty times more common in achlorhydric patients than in the general population, and more common in achlorhydric patients with hypogammaglobulinaemia (HGG) than in those with pernicious anaemia (PA) (Kinlen et al., 1985). Previous studies have failed to reveal major differences in the bacterial flora of samples of gastric juice from achlorhydric patients with HGG and PA (Dolby et al., 1984; Borriello et al., 1985); however, there was a greater tendency for

Received 4 Aug. 1986; revised version accepted 20 June 1987 Present address and address for offprint requests: Department of Paramedical Sciences, North East London Polytechnic, Romford Road, London E1 5 4LZ. nitrite to accumulate in the stomachs of $\mathrm{HGG}$ patients (Dolby et al., 1984). Nitrite is both a product of bacterial nitrate reduction and a precursor of carcinogenic N-nitroso compounds (Reed $e t$ al., 1981).

In an attempt to understand why nitrite accumulates in the stomachs of HGG patients we have determined rates of nitrate and nitrite reduction by pure cultures of bacteria isolated from the gastric juice of achlorhydric patients.

\section{Materials and methods}

\section{Subjects}

Eight patients with achlorhydria were studied with the approval of the Northwick Park Hospital ethical committee. Five had late-onset primary hypogammaglobulinaemia and three had vitamin B12-responsive pernicious anaemia. 


\section{Isolation, enumeration and identification of bacteria from gastric juice samples}

Samples of gastric juice were obtained by aspiration as previously described (Dolby et al., 1984) and placed immediately into an anaerobic cabinet (Forma Scientific, Marietta, OH, USA). Within $2 \mathrm{~h}$ of collection, serial dilutions of the juice were prepared anaerobically in reduced Brucella Broth (Difco) and used to inoculate anaerobic and aerobic media. Total anaerobic viable counts were obtained on Brain Heart Infusion (BHI) Blood Agar whilst selective media were used for the isolation of bacteroides (Borriello et al., 1978) and veillonellae (Macfarlane, 1977). All anaerobic plates were incubated for 5 days at $37^{\circ} \mathrm{C}$ in an anaerobic jar or cabinet. Campylobacter spp. were isolated on Skirrow's Selective Medium (Oxoid) incubated in micro-aerophilic conditions at $37^{\circ} \mathrm{C}$ for 5 days. Aerobic plates included blood agar, MacConkey's agar and selective media for staphylococci (Medium 110, Oxoid), haemophili (Wong et al., 1984) and lactobacilli (Rogosa et al., 1951). All plates were incubated aerobically at $37^{\circ} \mathrm{C}$ for 2 days. For haemophili and lactobacilli $\mathrm{CO}_{2} 10 \%$ was added to the atmosphere.

Isolates were routinely identified to genus level by standard methods and also to species level when the strain was of particular interest (Cowan, 1974). Cultures from the same patient which could not be distinguished from each other by the above tests were assumed to be isolates of the same strain and only one isolate was chosen for further study.

\section{Most probable number of nitrate- and nitrite- reducing bacteria}

The most probable numbers of nitrate- and nitritereducing bacteria in gastric juice were determined by a microtitration-tray method (Dolby et al., 1984). Briefly, $100-\mu 1$ volumes of BHI broth supplemented with potassium nitrate $(1 \mathrm{mM})$ or sodium nitrite $(0.1 \mathrm{mM})$ were inoculated in triplicate with ten-fold dilutions of gastric juice. The microtitration trays were incubated anaerobically for 5 days at $37^{\circ} \mathrm{C}$. Nitrate- and nitrite-reducing organisms were detected by adding nitrite colorimetric reagents. Zinc dust was added to nitrate media with no detectable nitrite to assay for complete nitrate reduction (Meynell and Meynell, 1970). The most probable numbers of nitrate- and nitrite-reducing bacteria were taken to be the highest dilutions with detectable activity.

\section{Screen for nitrate- and nitrite-reducing bacteria}

Apart from the modifications listed below, all strains were grown overnight in BHI broth supplemented with glucose $0.5 \%, 1 \mu \mathrm{M}$ sodium selenate, $1 \mu \mathrm{M}$ ammonium molybdate and $5 \mathrm{~mm}$ potassium nitrate. For isolates of Streptococcus sanguis and Neisseria subflava, potassium nitrate was replaced with $1 \mathrm{mM}$ sodium nitrite. Haematin $10 \mu \mathrm{g} / \mathrm{ml}$ and nicotinamide adenine dinucleotide $10 \mu \mathrm{g} /$ $\mathrm{ml}$ were added for haemophili. For veillonellae, glucose was replaced with sodium lactate $0.5 \%$ and the medium was degassed by evacuation and purging with oxygenfree nitrogen. A $0 \cdot 5-\mathrm{ml} \mathrm{sample} \mathrm{of} \mathrm{the} \mathrm{overnight} \mathrm{broth}$ culture was inoculated into narrow test tubes $(10 \mathrm{~mm} \times$ $100 \mathrm{~mm}$ ) containing $5 \mathrm{ml}$ of BHI broth supplemented as above. Cultures were incubated anaerobically at $37^{\circ} \mathrm{C}$ for 7 days. Samples were withdrawn daily and assayed for the presence of nitrate or nitrite. Gaseous products of nitrite reduction were collected in Durham's tubes. Bacteroides spp. were also tested for nitrate reduction with a modified indole-nitrite medium (Holdeman et al., 1977).

\section{Nitrate and nitrite reduction assays}

Bacteria were grown anaerobically to late exponential phase in BHI broth supplemented as described above. They were harvested by centrifugation, washed and then resuspended to a density of $8-32 \mathrm{mg} / \mathrm{ml}$ (dry weight) in nitrogen-saturated $50 \mathrm{~mm}$ sodium phosphate buffer $(p \mathrm{H}$ 7.5 unless indicated). Rates of endogenous nitrate and nitrite reduction were then determined in this buffer and in the same buffer with the addition of $60 \mathrm{~mm}$ glucose, $60 \mathrm{~mm}$ lactate or $60 \mathrm{~mm}$ formate as electron donor. Samples $(50 \mu \mathrm{l})$ were removed at regular intervals over 30 min and assayed for nitrate and nitrite (Cole and Ward, 1973). Results were expressed as nmol of product/min/ $\mathrm{mg}$ dry cell weight. Nitrate reduction by veillonellae was assayed in Bactopeptone sodium phosphate buffer (Oxoid) $1 \%$ because their ability to reduce nitrite was lost in simple sodium phosphate buffer.

\section{Determination of nitrate, nitrite and ammonia concentrations}

Nitrate was measured with the Szekely reagent (Faull et al., 1969). Nitrite was determined colorimetrically with sulphanilamide and N-1-napthyl ethylenediaminedihydrochloride (Radcliffe and Nicholas, 1968). Ammonia was detected by the indole-phenol method (Weatherburn, 1967).

\section{Results}

\section{Composition of the flora of gastric juice samples}

Although qualitative and quantitative differences were found between individual patients, the composition of the gastric juice flora was similar in HGG and PA patients (table I). C. pyloridis was isolated from two HGG patients and one PA patient.

Anaerobic viable counts were in the range $10^{6}$ $10^{8} \mathrm{cfu} / \mathrm{ml}$ of gastric aspirate and, for each sample, were equivalent to the most probable numbers of nitrate- and nitrite-reducing bacteria (table I). Nitrite was detected in six gastric aspirates, the highest concentration being $1.0 \mathrm{~mm}$ in patient HGG-1. 
Table I. Bacterial composition of fresh gastric juice from achlorhydric patients

\begin{tabular}{|c|c|c|c|c|c|c|c|c|}
\hline \multirow[b]{2}{*}{ Bacteria } & \multicolumn{8}{|c|}{$\begin{array}{c}\text { Viable count }\left(\log _{10} \mathrm{cfu} / \mathrm{ml}\right) \text { and nitrite concentration }(\mu \mathrm{M}) \text { in gastric juice from } \\
\text { patient }\end{array}$} \\
\hline & HGG-1 & HGG-2 & HGG-3 & HGG-4 & HGG-5 & PA-1 & PA-2 & PA-3 \\
\hline Streptococci & 7 & 7 & 6 & 7 & 6 & 8 & 7 & 8 \\
\hline Neisseria subflava & 6 & 6 & 4 & 6 & 5 & 6 & 6 & 8 \\
\hline Neisseria mucosa & 0 & 6 & 0 & 7 & 5 & 6 & 0 & 7 \\
\hline Veillonella alcalescens & 6 & 4 & 3 & 6 & 0 & 6 & 7 & 7 \\
\hline Haemophilus parainfluenzae & 6 & 6 & 6 & 7 & 3 & 7 & 6 & 8 \\
\hline Haemophilus influenzae & 0 & 6 & 0 & 6 & 0 & 0 & 0 & 0 \\
\hline Staphylococcus aureus & 0 & 0 & 5 & 4 & 4 & 4 & 6 & 5 \\
\hline Staphylococcus hominis & 0 & 0 & 5 & 6 & 4 & 0 & 0 & 0 \\
\hline Corynebacterium spp. & 6 & 6 & 5 & 0 & 5 & 6 & 6 & 0 \\
\hline Bacteroides spp. & 5 & 7 & 0 & 5 & 0 & 6 & 0 & 0 \\
\hline Escherichia coli & 0 & 0 & 4 & 4 & 0 & 0 & 6 & 7 \\
\hline Citrobacter freundi & 6 & 0 & 0 & 0 & 0 & 0 & 0 & 0 \\
\hline Klebsiella pneumoniae & 0 & 0 & 0 & 0 & 0 & 0 & 7 & 0 \\
\hline Lactobacilli & 5 & 0 & 5 & 0 & 0 & 8 & 5 & 8 \\
\hline Flavobacterium spp. & 0 & 0 & 0 & 5 & 0 & 4 & 0 & 8 \\
\hline Campylobacter pylori & 6 & 4 & 0 & 0 & 0 & 5 & nt & 0 \\
\hline Fusobacterium spp. & 0 & 0 & 0 & 5 & 0 & 0 & 0 & 0 \\
\hline Bacillus spp. & 0 & 0 & 0 & 0 & 0 & 0 & 7 & 0 \\
\hline Aeromonas hydrophilia & 0 & 0 & 0 & 0 & 0 & 0 & 5 & 0 \\
\hline MPN of nitrite reducers & 8 & 8 & 7 & 8 & 6 & 8 & 8 & $\mathrm{nt}$ \\
\hline MPN of nitrate reducers & 8 & 7 & 7 & 7 & 6 & 8 & 8 & nt \\
\hline Anaerobes (total) & 8 & 8 & 7 & 8 & 6 & 8 & 8 & 8 \\
\hline Nitrite concentration & 1000 & 440 & 22 & nt & nt & 33 & 73 & 93 \\
\hline
\end{tabular}

$0=$ Viable count $<10^{2}$.

$\mathrm{nt}=$ Not tested.

$\mathrm{MPN}=$ Most probable number.

\section{Screen for nitrate- and nitrite-reducing bacteria}

Over 500 isolates were screened for nitrate and nitrite reduction but 370 were not studied further because they were indistinguishable from other isolates from the same patients. At least some members from each genus, except Bacteroides, reduced either or both of these electron acceptors (table I). C. pylori isolates were not tested because of the difficulty of growing the organism in liquid culture.

All strains of staphylococci, veillonellae, haemophili and enterobacteria reduced nitrate and nitrite, as did the majority of the lactobacilli and corynebacteria (table II). All strains of flavobacteria and neisseriae tested reduced nitrite and three strains of $N$. mucosa also reduced nitrate. Twelve strains of streptococci reduced nitrite but only when haematin $10 \mu \mathrm{g} / \mathrm{ml}$ had been added to the growth medium; all were identified as Str. sanguis. Ammonium ions accumulated during nitrite reduction by all bacteria except the neisseriae, which reduced nitrite to gaseous products (table II).

\section{Whole-cell assays of nitrate and nitrite reduction rates}

Having established which bacteria reduced nitrate or nitrite during growth, the rates of nitrate and nitrite reduction by washed bacterial suspensions were then determined with a range of electron donors which might be expected to be available to bacteria in the stomach.

Nitrate-reduction rates varied considerably according to bacterial species and electron donor used (table III). Strains of Haemophilus parainfluenzae and enterobacteria reduced nitrate rapidly with all three electron donors, particularly with formate. Veillonellae were also rapid nitrate-reducers but only in the presence of lactate. No nitrate reduction by any fusobacteria was detected during an 8-h incubation period.

Rates of nitrite reduction were less variable. Most bacteria were more active in the presence of glucose than with lactate or formate, except haemophili which were again very active with formate as the electron donor. Highest nitrite- 
Table II. Distribution of nitrate- and nitrite-reducing strains among the bacterial species isolated from achlorhydric stomachs

\begin{tabular}{|c|c|c|c|c|}
\hline \multirow{2}{*}{ Bacteria } & \multirow[t]{2}{*}{$\begin{array}{c}\text { Number of strains } \\
\text { tested }\end{array}$} & \multicolumn{2}{|c|}{$\begin{array}{l}\text { Number of strains that } \\
\text { reduced }\end{array}$} & \multirow[t]{2}{*}{$\begin{array}{l}\text { Product of nitrite re- } \\
\text { duction }\end{array}$} \\
\hline & & nitrate & nitrite & \\
\hline Streptococci & 44 & 0 & $12^{*}$ & ammonia \\
\hline N. mucosa & 3 & 3 & 3 & gas \\
\hline N. subflava & 11 & 0 & 11 & gas \\
\hline$V$ alcalescens & 13 & 13 & 13 & ammonia \\
\hline H. influenzae & 2 & 2 & 2 & ammonia \\
\hline H. parainfluenzae & 9 & 9 & 9 & ammonia \\
\hline S. aureus & 10 & 10 & 10 & ammonia \\
\hline S. hominis & 5 & 5 & 5 & ammonia \\
\hline Corynebacterium spp. & 10 & 7 & 9 & ammonia \\
\hline Bacteroides spp. & 6 & 0 & 0 & $\ldots$ \\
\hline E. coli & 5 & 5 & 5 & ammonia \\
\hline C. freundi & 1 & 1 & 1 & ammonia \\
\hline K. pneumoniae & 2 & 2 & 2 & ammonia \\
\hline A. hydrophilia & 1 & 1 & 0 & $\ldots$ \\
\hline Lactobacilli & 8 & 4 & 6 & ammonia \\
\hline Flavobacterium spp. & 2 & 1 & 2 & ammonia \\
\hline Fusobacterium spp. & 1 & 1 & 0 & $\ldots$ \\
\hline Bacillus spp. & 2 & 1 & 2 & nt \\
\hline
\end{tabular}

$\mathrm{nt}=$ not tested.

* All were identified as Str. sanguis.

reduction rates were seen with neisseriae and flavobacteria.

\section{The effect of $\mathrm{pH}$ on whole cell nitrate- and nitrite-} reduction rates

To determine the effect of varying stomach $p \mathrm{H}$ on nitrate and nitrite reduction (and hence on the tendency for nitrite to accumulate or be removed) the rates of nitrate and nitrite reduction by washed bacterial suspensions were determined over the $p \mathrm{H}$ range 6-8 (table IV). The optimal rate of nitrate reduction with glucose was obtained between $p \mathrm{H}$ $7 \cdot 0$ and 7.5 for neisseriae, haemophili and corynebacteria. Nitrate reduction by lactobacilli, staphylococci and enterobacteria with glucose or lactate as electron donor was generally more rapid at $p \mathrm{H}$ 6.0. Nitrite reduction with glucose was greater at

Table III. Rates of nitrate and nitrite reduction by whole cells with various electron donors

\begin{tabular}{|c|c|c|c|c|c|c|c|c|c|}
\hline \multirow[b]{2}{*}{ Bacteria } & \multirow{2}{*}{$\begin{array}{c}\text { Number } \\
\text { of } \\
\text { strains } \\
\text { tested }\end{array}$} & \multicolumn{4}{|c|}{ Mean (SEM) nitrate reduction rate* } & \multicolumn{4}{|c|}{ Mean (SEM) nitrite reduction rate* } \\
\hline & & endogenous & $\begin{array}{c}\text { with } \\
\text { glucose } \dagger\end{array}$ & $\begin{array}{c}\text { with } \\
\text { lactate } \dagger\end{array}$ & $\begin{array}{c}\text { with } \\
\text { formate } \dagger\end{array}$ & endogenous & $\begin{array}{c}\text { with } \\
\text { glucose } \dagger\end{array}$ & $\begin{array}{c}\text { with } \\
\text { lactate } \dagger\end{array}$ & $\begin{array}{c}\text { with } \\
\text { formate } \dagger\end{array}$ \\
\hline Str. sanguis & 6 & 0 & 0 & 0 & 0 & $2(0 \cdot 3)$ & $23(12 \cdot 7)$ & $2(0 \cdot 5)$ & $2(0 \cdot 7)$ \\
\hline N. mucosa & 2 & 8 & 37 & 40 & 12 & 17 & 86 & 92 & 17 \\
\hline N. subflava & 3 & 0 & 0 & 0 & 0 & $34(19 \cdot 2)$ & $88(12 \cdot 2)$ & $94(18 \cdot 0)$ & 17 \\
\hline Veillonellae & 6 & $4(3 \cdot 7)$ & 0 & $216(33.7)$ & $10(4 \cdot 6)$ & $1(0.8)$ & 0 & $15(1.7)$ & $2(0 \cdot 9)$ \\
\hline H. parainfluenzae & 4 & $51(15.3)$ & $188(14 \cdot 3)$ & 168 & $649(50 \cdot 2)$ & $9(3 \cdot 3)$ & $44(10 \cdot 3)$ & 42 & $174(75 \cdot 6)$ \\
\hline S. aureus & 7 & $12(3.6)$ & $35(5 \cdot 7)$ & $36(12 \cdot 1)$ & $14(5 \cdot 3)$ & $2(0.7)$ & $29(4.9)$ & $8(3.4)$ & $2(0.8)$ \\
\hline S. hominis & 2 & 30 & 69 & 49 & 3 & 4 & 36 & 9 & 3 \\
\hline Corynebacteria & 11 & $19(5 \cdot 7)$ & $52(18 \cdot 3)$ & $30(12 \cdot 5)$ & $23(8 \cdot 2)$ & $14(7 \cdot 5)$ & $27(9 \cdot 2)$ & $22(12 \cdot 8)$ & $5(2.4)$ \\
\hline Lactobacilli & 5 & $4(0.9)$ & $12(2 \cdot 9)$ & $14(5 \cdot 0)$ & $2(1 \cdot 0)$ & $10(7.0)$ & $27(9 \cdot 8)$ & $24(12 \cdot 1)$ & $12(12 \cdot 3)$ \\
\hline Flavobacterium spp. & 2 & 28 & 114 & & 30 & 5 & 74 & 46 & 9 \\
\hline E. coli & 5 & $7(2 \cdot 3)$ & $90(5 \cdot 9)$ & $46(20 \cdot 3)$ & $200(42 \cdot 0)$ & $2(1 \cdot 0)$ & $48(5.9)$ & $4(1 \cdot 7)$ & $11(4 \cdot 7)$ \\
\hline C. freundi & 1 & 5 & 87 & 54 & 160 & 0 & 27 & 0 & 3 \\
\hline$K$. pneumoniae & 2 & 48 & 163 & $\ldots$ & 168 & 3 & 66 & $\ldots$ & 5 \\
\hline
\end{tabular}

$\ldots=$ not determined.

* Enzyme activity is expressed as nmoles of product $/ \mathrm{min} / \mathrm{mg}$ dry weight at $p \mathrm{H} 7 \cdot 5$; where there is no SEM the number of strains assayed was less than three.

$\dagger$ Rate of reduction is not corrected for endogenous rate. 
Table IV. Rates of nitrate and nitrite reduction with glucose or lactate as electron donors by whole cells in buffers of various $p \mathrm{H}$ values

\begin{tabular}{|c|c|c|c|c|c|c|c|c|c|}
\hline \multirow{2}{*}{$\begin{array}{c}\text { Bacteria (number of } \\
\text { strains) }\end{array}$} & \multirow{2}{*}{$\begin{array}{l}\text { Electron } \\
\text { donor }\end{array}$} & \multicolumn{4}{|c|}{ Mean nitrate reduction rate ${ }^{*}$ at $p \mathrm{H}$} & \multicolumn{4}{|c|}{ Mean nitrite reduction rate* at $p \mathrm{H}$} \\
\hline & & $6 \cdot 0$ & $7 \cdot 0$ & $7 \cdot 5$ & $8 \cdot 0$ & $6 \cdot 0$ & $7 \cdot 0$ & $7 \cdot 5$ & $8 \cdot 0$ \\
\hline Neisseriae (3) & $\begin{array}{l}\text { Glucose } \dagger \\
\text { Lactate } \uparrow \\
\text { Endogenous }\end{array}$ & $\begin{array}{r}19 \\
17 \\
7\end{array}$ & $\begin{array}{r}38 \\
41 \\
6\end{array}$ & $\begin{array}{r}30 \\
42 \\
4\end{array}$ & $\begin{array}{r}30 \\
37 \\
6\end{array}$ & $\begin{array}{r}51 \\
191 \\
35\end{array}$ & $\begin{array}{r}109 \\
150 \\
57\end{array}$ & $\begin{array}{r}143 \\
161 \\
80\end{array}$ & $\begin{array}{r}122 \\
118 \\
53\end{array}$ \\
\hline Veillonellae (4) & $\begin{array}{l}\text { Glucose } \\
\text { Lactate } \\
\text { Endogenous }\end{array}$ & $\begin{array}{r}0 \\
481 \\
11\end{array}$ & $\begin{array}{r}0 \\
359 \\
0\end{array}$ & $\begin{array}{r}0 \\
263 \\
10\end{array}$ & $\begin{array}{r}0 \\
205 \\
0\end{array}$ & $\begin{array}{r}0 \\
12 \\
2\end{array}$ & $\begin{array}{r}0 \\
17 \\
2\end{array}$ & $\begin{array}{r}0 \\
14 \\
2\end{array}$ & $\begin{array}{r}0 \\
14 \\
2\end{array}$ \\
\hline Haemophili (3) & $\begin{array}{l}\text { Glucose } \\
\text { Lactate } \\
\text { Endogenous }\end{array}$ & $\begin{array}{r}67 \\
177 \\
28\end{array}$ & $\begin{array}{r}173 \\
200 \\
17\end{array}$ & $\begin{array}{r}126 \\
174 \\
19\end{array}$ & $\begin{array}{r}111 \\
124 \\
10\end{array}$ & $\begin{array}{r}18 \\
97 \\
5\end{array}$ & $\begin{array}{r}48 \\
81 \\
0\end{array}$ & $\begin{array}{r}73 \\
75 \\
0\end{array}$ & $\begin{array}{r}53 \\
74 \\
0\end{array}$ \\
\hline Staphylococci (4) & $\begin{array}{l}\text { Glucose } \\
\text { Lactate } \\
\text { Endogenous }\end{array}$ & $\begin{array}{l}59 \\
58 \\
28\end{array}$ & $\begin{array}{l}41 \\
49 \\
27\end{array}$ & $\begin{array}{l}31 \\
40 \\
18\end{array}$ & $\begin{array}{l}26 \\
32 \\
17\end{array}$ & $\begin{array}{r}23 \\
20 \\
2\end{array}$ & $\begin{array}{r}40 \\
20 \\
3\end{array}$ & $\begin{array}{r}43 \\
12 \\
2\end{array}$ & $\begin{array}{r}39 \\
7 \\
3\end{array}$ \\
\hline Corynebacteria (4) & $\begin{array}{l}\text { Glucose } \\
\text { Lactate } \\
\text { Endogenous }\end{array}$ & $\begin{array}{l}20 \\
24 \\
13\end{array}$ & $\begin{array}{l}26 \\
28 \\
15\end{array}$ & $\begin{array}{l}25 \\
23 \\
13\end{array}$ & $\begin{array}{l}22 \\
19 \\
12\end{array}$ & $\begin{array}{r}29 \\
29 \\
2\end{array}$ & $\begin{array}{r}19 \\
19 \\
6\end{array}$ & $\begin{array}{r}13 \\
10 \\
5\end{array}$ & $\begin{array}{l}9 \\
7 \\
4\end{array}$ \\
\hline Lactobacilli (4) & $\begin{array}{l}\text { Glucose } \\
\text { Lactate } \\
\text { Endogenous }\end{array}$ & $\begin{array}{r}18 \\
26 \\
3\end{array}$ & $\begin{array}{r}20 \\
17 \\
3\end{array}$ & $\begin{array}{r}12 \\
15 \\
3\end{array}$ & $\begin{array}{l}8 \\
7 \\
4\end{array}$ & $\begin{array}{r}45 \\
34 \\
5\end{array}$ & $\begin{array}{r}41 \\
28 \\
5\end{array}$ & $\begin{array}{r}26 \\
18 \\
3\end{array}$ & $\begin{array}{r}18 \\
7 \\
4\end{array}$ \\
\hline Enterobacteria (3) & $\begin{array}{l}\text { Glucose } \\
\text { Lactate } \\
\text { Endogenous }\end{array}$ & $\begin{array}{r}77 \\
64 \\
1\end{array}$ & $\begin{array}{r}75 \\
48 \\
3\end{array}$ & $\begin{array}{r}78 \\
40 \\
4\end{array}$ & $\begin{array}{r}77 \\
25 \\
0\end{array}$ & $\begin{array}{r}24 \\
0 \\
0\end{array}$ & $\begin{array}{r}41 \\
0 \\
0\end{array}$ & $\begin{array}{r}39 \\
1 \\
0\end{array}$ & $\begin{array}{r}42 \\
0 \\
1\end{array}$ \\
\hline
\end{tabular}

* See footnote to table III.

$\dagger$ Rate of reduction is not corrected for endogenous rate.

$p \mathrm{H} 7 \cdot 0-7 \cdot 5$ for bacteria other than lactobacilli and corynebacteria. With the exception of veillonellae and enterobacteria, nitrite reduction with lactate as electron donor was more rapid at lower $p \mathrm{H}$ values.

Nitrite accumulation in mixed suspensions of $H$. parainfluenzae and N. subflava

Because suspensions of pure cultures of $H$. parainfluenzae reduced nitrate more rapidly than nitrite, the latter might be expected to accumulate in gastric juice in which this species was the dominant organism. Conversely, nitrite would tend to be reduced as rapidly as it was produced from nitrate by gastric juice in which $N$. subflava was more abundant than $H$. parainfluenzae. To test these predictions, suspensions of $H$. parainfluenzae $\left(10^{9} \mathrm{cfu} / \mathrm{ml}\right)$ were incubated, with $1.1 \mathrm{~mm}$ nitrate and glucose, and with various concentrations of $N$. subflava in the ratios $9: 1$ to $1: 9$. The concentration of nitrite which had accumulated in the mixed suspension during incubation at $37^{\circ} \mathrm{C}$ was determined at frequent intervals (figure).

Nitrite was not detected in suspensions in which
$N$. subflava outnumbered $H$. parainfluenzae in the ratio 9:1. There was a transient accumulation of nitrite when this ratio decreased to $3: 1$ and both the duration of nitrite accumulation and the peak nitrite concentration increased as this ratio progressively decreased. When $H$. parainfluenzae outnumbered $N$. subflava by $9: 1$ the highest concentration of nitrite detected was $0.9 \mathrm{~mm}$, less than the initial concentration of nitrate added to the suspension.

\section{Discussion}

The bacterial flora of the achlorhydric stomach was very similar to that of the oropharynx with a predominance of streptococci, veillonellae and neisseriae (Drasar et al., 1969; Marsh and Martin, 1984). This contrasts with the bacterial flora of the lower gut in which bacteroides and bifidobacteria are the most abundant bacteria. Neisseriae and haemophili were isolated more frequently than during a previous study of HGG patients (Borriello et al., 1985), possibly because in the earlier study samples of gastric juice were stored frozen before analysis and a selective medium was not used to isolate haemophili. C. pylori was isolated from three 


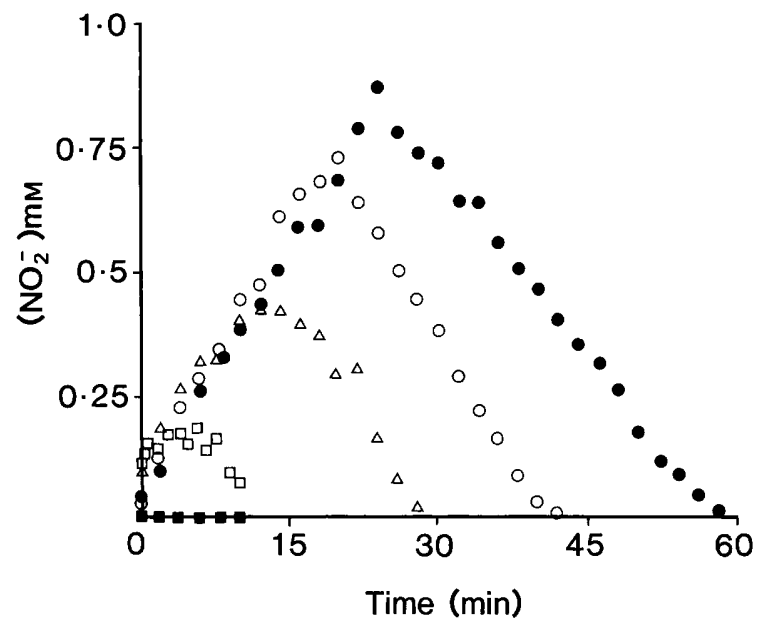

Figure. Nitrite accumulation during nitrate reduction by mixed cultures of $N$. subflava and $H$. parainfluenzae in ratios of $0.11: 1$ to $9: 1$. The final cell density of the nitrite-accumulator $(H$. parainfluenzae) was $1 \times 10^{9} \mathrm{cfu} / \mathrm{ml}$. Glucose was the electron donor. Assays were started by the addition of potassium nitrate (final concentration $1.1 \mathrm{mM}$ ) and were done at $37^{\circ} \mathrm{C}, p \mathrm{H} 7.5$. Key: Ratio of $N$. subflava to $H$. parainfluenzae. $-0.11: 1 \cdot 0$; $\bigcirc-0 \cdot 33: 1 \cdot 0 ; \triangle-1 \cdot 0: 1 \cdot 0 ; \square-3 \cdot 0: 1 \cdot 0 ; \square-9 \cdot 0: 1 \cdot 0$.

of the gastric aspirates of the eight patients sampled (table I). This is the first report of $C$. pylori being isolated from the stomach of a patient with HGG although it has previously been isolated from patients with PA and is known to be associated with gastritis (Goodwin et al., 1986).

The most abundant bacteria of the gastric flora were able to reduce nitrate or nitrite. This was confirmed by the isolation of nitrite-reducing streptococci and neisseriae and nitrate- and nitritereducing haemophili (tables $\mathrm{I}$ and II; see also Drasar and Hill, 1974). The $\mathrm{pH}$ of gastric juice from the achlorhydric stomach is in the range $6 \cdot 0-8 \cdot 0$ and this coincides with the $p \mathrm{H}$ range over which nitrate and nitrite reductases were active. Although these activities varied with $p \mathrm{H}$, the tendency for a particular bacterial group to accumulate nitrite during nitrate reduction remained. For example, although nitrate reduction by veillonellae was slower at $p \mathrm{H} 8.0$ than at $p \mathrm{H} 6.0$, even at $p \mathrm{H} 8.0$ the nitrite reduction rate was only $7 \%$ of the nitrate reduction rate (table IV). Conversely nitrite did not accumulate during nitrate reduction by $N$. mucosa over the same $p \mathrm{H}$ range because of the higher rates of nitrite reduction than nitrate reduction.

The potential rates of nitrate and nitrite reduction by various groups of bacteria in the stomach can be estimated from the product of the population densities and whole-cell reduction rates. The presence of veillonellae and haemophili would tend to lead to nitrite accumulation whereas nitrite would tend to be removed by Str. sanguis and neisseriae. Results of experiments with mixtures of $H$. parainfluenzae and $N$. subflava were consistent with this prediction. It will be interesting to test whether similar predictions are fulfilled by other combinations of bacteria, e.g., mixtures of veillonellae and streptococci.

The extrapolation of results of in-vitro experiments may be misleading. The electron donors for nitrate and nitrite reduction in vivo have not been determined, although glucose, produced from dietary carbohydrates, and lactose would be fermented to lactate by the streptococci. Furthermore, the methods used to estimate cell densities in gastric juice are only accurate to one order of magnitude and single gastric juice samples are not representative of the daily variation in nitrite concentration.

Despite these reservations some general conclusions may be drawn. Nitrite would tend not to accumulate in a stomach colonised predominantly by streptococci and neisseriae; an example of this type of flora was found in the gastric juice from patient HGG-4 in which any nitrite produced by the haemophili would be metabolised by the more prolific streptococci and neisseriae. In contrast, the accumulation of nitrite in the gastric juice of patient HGG-1 may be attributed to the high population densities of veillonellae, haemophili and citrobacters which are able to reduce nitrate rapidly.

Staphylococci were not isolated from the gastric juice of patients HGG-1 and HGG-2. The concentration of nitrite was higher in these than in the other six samples, suggesting that the normally abundant staphylococci either play a major role in the removal of nitrite or that they produce metabolites essential for the expression of nitrite reductase by more dominant organisms. The former possibility is not supported by the data of their population densities and nitrite reductase activities. However growth stimulation of haemophili by $\mathrm{NAD}^{+}$produced by Staphylococcus aureus is an example of an interaction that might be important in this microniche.

In conclusion we have established that the predominant bacteria in the achlorhydric stomach were able to reduce nitrate and nitrite with glucose or lactate as the electron donor. The accumulation of nitrite in the achlorhydric stomach may be related to the presence of haemophili and veillonellae in the bacterial flora.

We thank Dr S. P. Borriello for many constructive discussions, Mary Stephenson for her technical assistance and the Cancer Research Campaign for financial support. 


\section{REFERENCES}

Borriello S P, Hudson M, Hill M J 1978 Investigation of the gastrointestinal bacterial flora. Clinics in Gastroenterology 7:329-349.

Borriello S P, Reed P J, Dolby J M, Barclay F E, Webster A D B 1985 Microbial and metabolic profile of the achlorhydric stomach: comparison of pernicious anaemia and hypogammaglobulinaemia. Journal of Clinical Pathology 38:946-953.

Cole J A, Ward F B 1973 Nitrite reductase-deficient mutants of Escherichia coli K12. Journal of General Microbiology 76:2129.

Cowan S T 1974 Cowan and Steel's Manual for the identification of medical bacteria, 2nd edn. Cambridge University Press.

Dolby J M, Webster A D B, Borriello S P, Barclay F E, Bartholomew B A, Hill M J 1984 Bacterial colonization and nitrite concentration in the achlorhydric stomachs of patients with primary hypogammaglobulinaemia or classical pernicious anaemia. Scandinavian Journal of Gastroenterology 19: 105-110.

Drasar B S, Hill M J 1974 Reduction of a nitro group, nitrate or nitrite. In: Human intestinal flora. Academic Press, London, pp 88-90.

Drasar B S, Shiner M, Mcleod G M 1969 Studies on the intestinal flora. 1. The bacterial flora of the gastrointestinal tract in healthy and achlorhydric persons. Gastroenterology 56:7179.

Faull K F, Wallace W, Nicholas D J D 1969 Nitrite oxidase and nitrate reductase in Nitrobacter agilis. Biochemical Journal 113: 449-445.

Goodwin C S, Armstrong J A, Marshall B J 1986 Campylobacter pyloridis, gastritis, and peptic ulceration. Journal of Clinical Pathology 39: 353-365.
Holdeman L V, Cato E P, Moore W E C 1977 Anaerobe laboratory manual, 4 th edn. Anaerobe Laboratory, Virginia Polytechnic Institute and State University, Blacksburg, USA.

Kinlen L J et al. 1985 Prospective study of cancer in patients with hypogammaglobulinaemia. Lancet 1:263-266.

Macfarlane T W 1977 A semiselective medium for the isolation of Veillonella species from the mouth. Journal of Clinical Pathology 30: 191-192.

Marsh P, Martin M 1984 Oral microbiology 2nd edn. Aspects of Microbiology, vol. 1, Van Nostrand-Reinhold (UK) Co. Ltd, Wokingham.

Meynell G G, Meynell E 1970 Theory and practice in experimental bacteriology, 2nd edn. Cambridge University Press, Cambridge, pp 231-236.

Radcliffe B C, Nicholas D J D 1968 Some properties of a nitrite reductase from Pseudomonas denitrificans. Biochimica et Biophysica Acta 153: 545-554.

Reed P I, Haines K, Smith P L R, House F R, Walters C L 1981 Gastric juice $N$-nitrosamines in health and gastroduodenal disease. Lancet 2:550-552.

Rogosa M, Mitchell J A, Wiseman R F 1951 A selective medium for the isolation and enumeration of oral and fecal lactobacilli. Journal of Bacteriology 62: 132-133.

Weatherburn M W 1967 Phenol-hypochlorite reaction for determination of ammonia. Analytical Chemistry 39:971974.

Wong K, Roberts M C, Owens L, Fife M, Smith A L 1984 Selective media for the quantitation of bacteria in cystic fibrosis sputum. Journal of Medical Microbiology 17:113119. 